\title{
Enhancing student retention rates on open non-formal online language learning courses
}

\author{
Neil Cowie \\ Okayama University \\ ncowie2012@gmail.com \\ Keiko Sakui \\ Kobe Shoin Women's University, Kobe, Japan \\ ksakui2005@yahoo.co.jp
}

Submission Type: Brief Presentation (20mins + 10minsQ\&A)

Keywords: online learning; course design; student retention; EFL

\begin{abstract}
:
Open non-formal online courses (Rha, 2018) are becoming increasingly popular as a self-paced option for learners. These courses are often hosted by commercial platforms where teachers and course creators develop and market courses to students across the globe. The numbers of students enrolled on these kinds of courses is hard to estimate but figures from providers do indicate the numbers are significant. For example, the Udemy course provider (https://www.udemy.com) states that as of October 2019 it has over 30 million students learning on 50,000 courses. However, the attrition rates for such courses, similar to other online options such as MOOCs, can be high (Sánchez-Elvira Paniagua \& Simpson, 2018). In this presentation two teacher-researchers reflect on and analyse their experience of creating open non-formal online courses for English language learners, and go on to suggest several practical techniques to decrease the number of students that may drop out. The theoretical framework for this paper is that of exploratory practice (Allwright, 2003). This is an approach to teacher development in which teachers collect information on their courses and then try to use that data to reflect on their practice and improve conditions for learning. The two sources of data are the meta analytics supplied by Udemy for every course and surveys from university students who were asked to evaluate different types of video. These two sources of data were analysed using a two-step coding approach (Miles, Huberman \& Saldana, 2014) in which codes are assigned and then grouped together based on emergent themes. In the presentation, firstly, the wider reasons why online students drop out, such as insufficient support (Simpson, 2017) or the impact of cognitive overload (Sweller, Ayres \& Kalyuga, 2011), are discussed and several ways are suggested to get around these issues. Secondly, various principles of instructional design such as keeping lessons consistent but variable, relevant, and divided into manageable chunks are recommended (Lehman \& Conceição, 2014). Finally, a number of ways that videos can be made more engaging are shown (Mayer, 2017), especially focusing on how a talking head can be best portrayed in order to give the clearest information and develop a more personalised teacher presence (Garrison, 2011). Although the data and analysis are focused on open nonformal online courses the findings and discussion are of relevance to other forms of online instruction and multimedia learning.
\end{abstract}

\section{References}

Allwright, D. (2003). Exploratory practice: Rethinking practitioner research in language teaching. Language Teaching Research, 7(2),113-141. https//doi.org/10.1191/13621688031r118oa

Garrison, D. R. (2011). E-learning in the 21st century: A framework for research and practice. (2nd ed.). New York, NY: Routledge. http://dx.doi.org/10.4324/9780203166093

Lehman, R., \& Conceição, C. (2014). Motivating and retaining online students. San Francisco, CA: JosseyBass.

Mayer, R. E. (2017). Using multimedia for e-learning. Journal of Computer Assisted Learning, 33, 403423. https//doi.org/10.1111/jcal/12197

Miles, M.B., Huberman, A.M., \& Saldana, J. (2014). Qualitative Data Analysis: A Methods Sourcebook. London: Sage. 


\section{SoTEL Symposium 19-20 February 2020}

Rha, H.M. (2018). A study on the classification of online education types and development of quality management indicators for lifelong vocational skills development. In T. Bastiaens et al.

(Eds.). Proceedings of EdMedia: World Conference on Educational Media and Technology (pp. 759763). Amsterdam, Netherlands: Association for the Advancement of Computing in Education (AACE). Retrieved from https://www.learntechlib.org/p/184274.

Sánchez-Elvira Paniagua, A., \& Simpson, O. (2018). Developing student support for open and distance learning: The EMPOWER project. Journal of Interactive Media in Education, 1(9), 1-10, https://doi.org/10.5334/jime.470

Simpson, O. (2017). Innovations in distance education student support: What are the chances? In: G. Ubachs, L., Konings, \& M. Brown (Eds.). The Envisioning Report for Empowering Universities (pp. 52-55). Available from: https://empower. eadtu.eu/images/report/The_Envisioning_Report_for_ Empowering_Universities_1st_edition_2017.pdf

Sweller, J., Ayres, P., \& Kalyuga, S. (2011). Cognitive load theory. New York, NY: Springer. 